\title{
Marketing of luxury events. Case study on the tenth Congress of anti-aging medicine, Bucharest, 2018
}

\author{
Nicolae Al. POP \\ The Bucharest University of Economic Studies, Bucharest, Romania \\ nicolae_al_pop@yahoo.com \\ Cristina-Maria 0TT \\ The Bucharest University of Economic Studies, Bucharest, Romania \\ cristina_ott@ymail.com \\ Daniela SIMION \\ The Bucharest University of Economic Studies, Bucharest, Romania \\ danielle_simion@yahoo.com \\ Monica Z0TTU-Z \\ The Bucharest University of Economic Studies, Bucharest, Romania \\ monica.zottu@gmail.com
}

\begin{abstract}
Medicine and the pharmaceutical industry have a long and rich history of events. The transition from magic to modern medication was gradually achieved over thousands of years of evolution. Ambroise Pare, a French anatomist and surgeon from the 16th century, stated that it was very simple: "The doctor cares, God heals." The medical-industrial complex appears to grow much faster than the economic power. And this is because the system is oriented not only by the demand, but also by doctors who play a double role. They offer medical services and, at the same time, they control their need (demand). Along with human and technological evolution, in some countries of the world, medicine can be inaccessible, perhaps untouchable or it is even considered to be a luxury. In this case, luxury is presented in the form of rationality that draws the medical world at various congresses, where the only words that can characterize the event are: the performance, high-class, luxury and international reputation of the doctors or of the speakers. This article briefly outlines the results of a qualitative marketing research among medical congress organizers-social events where high-quality marketing blends nicely with the quality of modern medicine news and perspectives, thus forming a clearer picture of the tradition and the priorities of topics chosen for medical events. The result of the research is reflected in the sketch of a program of such an event in Romania, combining the high scientific performance with social elements that can significantly increase the attractiveness of such a manifestation. In order to obtain a conclusive feedback, a useful tool is also developed and accessible to the organizers. The bibliography supports theoretically the concepts with which it operates (event marketing, the significance of high-class professional performance and the specific coordinates of the medical sector).
\end{abstract}

Keywords: classic vs. modern medicine, event marketing, exploratory marketing research, marketing programme, high-class, luxury.

\section{Introduction}

With the passing of time, the universe of communication has been developed considerably. The implementation of the new technology has literally modified the standards which had been set for years. This current of change has also had an impact upon the demand, and 
people are becoming more and more imperceptible to traditional media, which they consider too homogeneous. In the age of hyper segmentation, must be chosen the most efficient, safe and simple but complex method of research must be chosen (Saget, 2006).

Therefore, we can talk about a new form of marketing and new strategies for its implementation: marketing and event communication (Shone, 2010).

The concept is simple: creating the event - the author of a product, a service, or a brand, for advertising and marketing, in order to raise the interest of potential customers who may want the new product or service promoted (Hoyle, 2002).

What distinguishes marketing from traditional events is its dynamism and shortterm action (Bladen et al., 2011). Events can take many forms: fairs and exhibitions, street marketing, online presentations, conferences, congresses, etc. (Allen, 2004).

Event marketing responds to well-defined objectives, but it can also encounter some obstacles. What is the usefulness of event marketing? What are its advantages and disadvantages? How do marketers apply it? Can the impact of the results of a promotion event be measured? What are the encountered obstacles?

The results of qualitative research, conducted among event organizers, in this case, the high-class medical congresses will answer the questions listed above and will clarify the issue of organizing luxury healthcare events.

\section{Literature review}

\section{Medical events - a luxury or a necessity?}

Since ancient times, the definition of luxury has been a controversial topic (Bastien, 2009). Luxury does not mean only fashion, diamonds and precious stones, top destinations trips, yachts or private jets (Bogdan, 2012). The concept of luxury has multiple meanings, both in terms of evaluating its content, the space which is being analyzed, or the population groups to which it refers. The literature (Bastien et al., 2009) presents the concept in the relationship between the individual and the society. From this point of view, we can define luxury as a social marker or luxury for oneself or the analysis of luxury. Luxury in the contemporary society is required to be analyzed in terms of its objectives or its beneficiary or wishes, as well as the general level of development of the society in which it is recorded. The definitions of luxury are numerous and differ according to gender, level of education, social class, geographic location, etc. Thus, we can say that a $\$ 1,300$ Louis Vuitton bag is a luxury asset for a person with an average income, but not the same as Victoria Beckham's possession of the most expensive handbags - a Hermes Birkin bag with white nylon crocodile and diamonds worth no less than \$432,000 (qmagazine.ro). With reference to consumer goods, water and food can be considered a luxury for Congo`s habitants who are declared to be the poorest country in the world in 2016, according to Business Magazine, where a resident can earn $\$ 40$ a month (businessmagazin.ro).

By referring to the subject of this article, medicine can be considered a luxury, Geographic location, educational level and per capita income are the key factors that can answer this question. Comparing the American, French, and Romanian health systems, we can discover a multitude of strengths and weaknesses for each of them (Tandon, 2000).

In both the US and France, but also in Romania, we are talking about an anachronistic, non-transparent system with major differences in the quality of health care (Enachescu, 1998) which depends on the country's region, social class, depends on the 
hospital and especially the physician's reputation. The same can be said about medical events, namely medical congresses.

There are many factors that reflect the fact that these events can be considered a luxury, a high-class manifestation, beginning with the event's tradition and fame, the poster and its promotion, the accuracy of the information and experiments presented, the choice of location and partners, the quality of the food offered to the guests, as well as the influence of the customer relationship management, which can satisfy the participants' potential of interest and later its loyalty (Pop, 2006).

\section{Marketing of medical events}

Event marketing tends to occupy a special place in the contemporary cultural landscape. It is considered to be a powerful communicational vector, which allow for differentiation in the saturated space of traditional advertising that particularly uses, in particular, communication through the media causing a real "emotional shock" that gives energy to this form of action in the service of goals, taking into account the dynamics of free time chosen to be spent by the stakeholders (Pop, 2011).

Events are components of the economic and social environment (Brătucu et al., 1999) and they are real communication and marketing tools that can be used in order to meet marketing objectives.

Lately, the importance of events has grown progressively and the occasions with which they can be performed are virtually limitless (Stăncioiu, 2005), the limit being imposed by the imagination of those who create it.

Event marketing is considered to be a progress through which an event is planned, prepared, created and delivered (Florescu et al., 2003).

This process includes assessing, defining, acquiring, allocating, controlling and analyzing time, human and financial resources of products, services and other resources to achieve the goals (Genadinik, 2014).

Event organizers must supervise every aspect of the event, including research, planning organization, control and evaluation of design and implementation of activities (Hoyle, 2002).

Marketing of medical events should highlight, in addition to promotional activity, product policy, price policy, distribution policy, staff policy, environment and partnership policy and sponsorship policy.

The strategic objectives of medical events aim on the one hand, at educating and informing the medical market (Pike, 2008) and taking into account that the technology evolves very quickly, their corresponding training, improving the cooperation between the medical departments in order to eliminate the causes that contribute to the differences that may occur between the promised service and the actual delivery.

Medical events should be viewed from a variety of perspectives, the opinion of all actors involved in organizing and developing tourism event in a particular region: the perspective of the local community, especially residents, the tourists' perspective, which are active participants or spectators at the event, the perspective of the stakeholders, mainly the organizers and partners involved in the actual happening the events (Ingram, 2014).

Investments in the medical field, attract an increase in medical tourism and, definitely, in the economic environment. Medical events attract many medical and 
pharmaceutical professional who meet and work together to exchange and share information and experience, helping them in their professional development.

The consideration of the international feature of medical events is the value, quality and prestige of events, as well as their doubtable effectiveness in generating new opportunities (Kotler, 2002), the existence of a particular interest in the purchase of products, services and technologies, especially from the top industrial fields, exposed to the events in question.

The percentage of exhibitors or promoters in international events varies greatly depending on: their importance, value and prestige, the level of economic and industrial development (the dimension and the absorption capacity of the markets), the host country or the local host of events, infrastructure, business facilities and comfort.

Specialized events are in line with the expansion of the number, the themes diversification (Raj et al., 2009), the geographic areas, where they are organized and, especially, their specialization tendency, in order to serve more efficiently and comprehensively the business objectives of all those who are involved in the implementation and participation.

Specialized medical events are on an ascendant path in terms of quality, speed of development and diversification, contribution to achieve business objectives and economic development. Specialized medical events accompanied by small demonstration exhibitions are addressed to scientific research, new high technology, where are presented and exposed only products processes, technologies, elements that are new on the market are presented and exposed. The target audience is represented by recognized specialists in the medical field.

\section{Experiential marketing of medical events}

It can be argued that it has gone through an experience-based economy because the experience affects the behavior of the stakeholders. The Paradigm of the Experiential Economy refers to experience as a distinct offer, occupying a central place in society and having an important place for the value of economic progress by goods, products and services.

The purpose of experiential marketing is to create a connection between a product/service and a life experience, that is relevant to the audience, so that they can discover the characteristics of the service/product on their own rather than being exposed to a passive environment of promotion and mass communication. Attention is directed from the meeting consumer's needs, to create emotional involvement by bringing to life.

Consequently, the success of any medical event depends on the way in which organizers succeed in giving authenticity through the experience of participating at that event. Authenticity has become the new sensitivity that the consumers are looking for, being willing to pay more to receive it.

\section{Medical events market in Romania}

Congresses and conferences are an important part of business and professional tourism (Lhomme, 2000), both in quantitative and qualitative terms. Congresses and conferences contribute to the exchange, transmission and deepening of knowledge and experience, but also to generating income and employment in the congress region. 
The event industry generates annually billion Euros, the most successful countries being Germany, with 65 billion Euros registered in 2015, and the UK with 50 billion Euros. According to APIER (Association of Professionals of the Event Industry in Romania), our country ranks the 26th out of 35 countries at a European level in the event organization and registered an income of 350 million of Euros in 2015.

On the other side, according to the latest edition of the International Meetings Statistics Report published by UIA (Union of International Associations), Dubai is one of the top destinations for organizing international events. The UIA report has classified 1157 cities by the total number of international events that took place over the past year. Dubai is the only Middle East city to appear in the top 25 in the world, which highlights the region's leading status as a destination for international conferences and events.

The organization of important medical conferences and congresses in Romania in the recent years, which have been carried out in very good conditions, has generated a positive perception of Romania as a destination for international meetings. The main elements that built this perception are: the existence of a general good infrastructure that allows organizing events with more than 2000 participants, the professionalism of the specific service providers (organization, event management, interpreters, technical services, transport, catering, banking, etc.).

The health sector continues to be one with many events, with the greatest impact being those of beauty and wellness, sports and nutrition that promote a healthy lifestyle. The most important medical events in Romania are organized in six major counties: Bucharest (market for 70\% of events), Braşov, Sibiu, Cluj-Napoca, Timişoara and Iaşi.

Many of the distinguished Romanian personalities are honored in the history of medicine of the last centuries. Several personalities are acknowledged today by the unanimous contribution, even though in the era these heroes have not always occupied the place they deserve. An absolutely exceptional name is Ana Aslan, an academic and specialist in gerontology. She developed Gerovital (vitamin H3) and founded the first geriatric institute in the world, "The National Institute of Gerontology and Geriatrics Dr. Ana Aslan", which was to represent, both through clinical assistance and research, a model for civilized countries. Some of the most remarkable figures of the twentieth have been treated at this institute and used the products invented by Ana Aslan such as J. F. Kennedy, I. B. Tito, Pablo Neruda, Charlie Chaplin, Salvador Dali, Indira Gandhi, Charles de Gaulle, Nikita Khrushchev, Aristotle Onasis and Marlene Dietrich (enciclopediaromaniei.ro).

\section{Methodology}

The applicative part of the study is intended to design a marketing program for the development of a high-performance medical program in the medical sector. A qualitative exploratory marketing research has been carried out (Kress, 1988; Plăiaș, 2008; Malhotra, Birks, 2003; Levens, 2012). The research protocol specifies the use of the semi-structured free discussion, using the in-depth interview technique, and as a tool the conversation guide doubled by a questionnaire with preceded questions using the Likert scale (Plăiaș, 2008; Cătoiu, 2009). To test the hypotheses formulated, the observation method was used. Our purpose was to unravel those events that can complete the overall image of our country. The objective of the research is to attempt an international repositioning of the medical event by increasing the ranking of the country because Romania has had an indisputable tradition in the field through the contribution of academician Ana Aslan. The research was 
conducted amongst the people organizing the event (scientific secretary of the congress and the executive part), the participants and all those involved logistically in the success of the event.

The studied event was "The tenth Congress of Anti-Aging Medicine 2018", to be held in Bucharest on 11-13 May 2018. This anniversary edition aims at increasing the scientific and technological level to which the participants were accustomed in order to create a memorable event from the scientific, logistical and exhibition point of view. The international support of the event, the professional and scientific reputation of those who will deliver presentations and workshops, the logistics, the material and human resources of this event, the names and reputation of the exhibitors are confirmations of a valuable environment leading to the exchange of information and technical, scientific and human experience. The 2018 anniversary edition will continue the tradition of modest fees for attending the event in Romania compared to similar events worldwide, the scientific committee and the association promoting a more open approach to this medical branch both from practitioners and especially from the developers of equipment, techniques, technologies and materials dedicated to this medical branch in progress and continuous development. The social approach takes this specialization beyond trends, current and fashion, transforming anti-aging medicine into a social necessity with major implications for quality of life and individual performance.

The following hypotheses were formulated:

Specific hypothesis - organizers:

H1: Attracting as many exhibitors as possible with an internationally recognized reputation is the key to the overall success of the event.

Specific hypothesis - HoReCa:

H2: Achieving a good image of the event: the appearance, order, decoration, the serious atmosphere and the high technical endowment of the exhibition complex and the venues of the event is the second important component of a success event.

Specific assumptions - participants:

H3: The perception of the participants appears as a high professional necessity in raising the reputation, in relation to the high quality of the event.

H4: Professional performance directly influences the participation to medical events.

H5: Participants see the event as an optimal meeting and communication environment for more potential partners.

\section{Results and discussions}

Analyzing the discussions we had with the organizers of the event it emerged that the prestige of the international participants, the quality and the constant attendance at the event are the key to the success of the whole action. The high level of internationalization gives the event high quality, value and prestige, especially recognized at an international level. They are also the premise that increases the attractiveness of the event among professional participants for its future editions. The involvement in the economic development of the hosting country of origin of the event is a major objective and responsibility, whose success has a positive implicit influence on the perspective of the development of the Romanian medical science ensemble, as the congress organizers stated. Therefore, the H1 hypothesis is confirmed. 
The conference rooms are small and intimate or large and sumptuous and can accommodate between 10 and 700 guests. All event rooms are equipped with: high-speed WiFi internet, video projector, screen for projections, flip chart. The halls were designed and equipped to provide all the necessary conditions for the successful organization of any type of event: conferences, presentations, workshops, symposiums, seminars, team building programs, social events (weddings, baptisms, of companies / reception) with up to 700 guests. The design of the room is very important but also the location. The majority of the medical congresses take place in Bucharest or in Romania`s top spa resorts: Poiana Brașov, Băile Tușnad, Băile Govora, Călimănești-Căciulata, Covasna, Băile-Felix, Sovata, Turda. Also, the service quality is one of the key factors of the conference's success. This is the main reason why the majority of the congresses are organized in $4^{*}$ or $5^{*}$ hotels, where participants can benefit from a wide range of top services - access to the spa and swimming pool, top accommodation, room service, meals included in the price, optional trips in the area, airport shuttle etc. The overall atmosphere of the event plays an important role in the participants' satisfaction. Thus, the atmosphere created during coffee breaks, or the lunch break, the quality of served meals, which lead to the establishment of relationships, or various partnerships among the participants, is valuable and leads to the success of the event. Taking into consideration all of the above reasons, $\mathrm{H} 2$ is confirmed.

The participants interviewed claim that it has always been a pleasant experience that has helped them learn new techniques and gave them ideas that they could put into practice. In addition, respondents declare that the trend of presenting treatment strategies with emphasis on scientific evidence is highly appreciated. Also, the participation provides the opportunity to get acquainted with the latest techniques and treatments in the field, which validates the hypothesis H3. In addition, more than $50 \%$ of participants in these conferences have participated at least once during the last five years, namely $42.8 \%$ attended two to three times, and $21.4 \%$ had more than three participations.

As every time at this event, dermatologists in the country and abroad gather to present and discuss clinical cases and novelties in dermatological pathologies that give them the opportunity to get acquainted with the latest innovations in the field. Therefore, the H4 hypothesis is confirmed.

The opportunity to socialize in a scientific environment is one of the main characteristics that congress participants are looking for. International participation is motivated by factors such as previous involvement and a positive image of host destination. Participation to the event provides an opportunity to meet experts in the field and to engage in partnerships. Through inter-human relationships that develop during these meetings, specialists from all over the world enter into network connections (Kotler et al., 2002). Relationship marketing is today the natural way of conceiving, cultivating and valorizing the social relationships in any field, and specially the medical field. Therefore, the H5 hypothesis is confirmed.

\section{Conclusion}

Education and health are the main engines of a nation's progress. Romania has taken important steps in improving the health and education system, but it still has many problems that it is currently facing. Education through congresses and conferences influences the growth, productivity, it contributes to people's personal and social 
development, and it also reduces social inequalities. In this way, congresses and conferences have the potential to play a vital role both in the economic and social contexts.

The multitude of options from the package of benefits they receive in exchange for the fees justify why event marketing is one of the most profitable industries. In addition, certain events shape their own brand.

The theme of congresses in the medical world is attacking both the prevention and healing of certain diseases. Not only through the therapeutic solutions offered for treating various illnesses, but especially for identifying the methods of prevention, the medical world gains significantly from these scientific manifestations.

The professional event organization is a component of the hospitality industry and generates positive image and substantial revenue in the destination where the event is held. It can be considered as an efficient and profitable component of tourism. Among the factors contributing to the success of the event are the number of participants, the international attention given to the event, the perceived improvement of the image and the pride of the host region, a special experience, but also style elements (such as hospitality, symbolism, authenticity), the fulfillment of several goals and the attraction for stakeholders and audiences. In addition, the interactive character of the event (person-person or personsetting) strengthens a higher level of involvement and commitment, making it a crucial element in the design of the experience and to the success of the event (Getz, 2016).

\section{Bibliography}

Allen, Judy, (2004). Marketing Your Event Planning Business: A Creative Approach to Gaining the Competitive Edge, Mississauga, ON: John Wiley \& Sons.

Angheluta, B. (2017, June). Care este cea mai săracă țară din lume. Retrieved from www.businessmagazin.ro/analize/care-este-cea-mai-saraca-tara-din-lume-undelocuitorii-castiga-mai-putin-de-400-de-dolari-pe-an-15452941

Bastien, V., Kapferer, J.N. (2009). Luxe oblige, Paris: Edition d'Organisation, p. 48.

Bladen, C. et al. (2011). Events Management: An Introduction, London: Routledge, 2nd Edition, pp. 2-4.

Bogdan, A. (2012). Branding pe frontul de est. Despre reputatie impotriva curentului, Ed.II, Bucuresti: Brandient Consult, pp. 78-80.

Brătucu, G., Ispas, A., Chițu, I.B. (1999). Marketingul serviciilor publice, Braşov: Ed. Infomarket, pp. 32-33.

Case Studies (International Association of Professional Congress Organizers) (2017). Retrived from www.iapco.org/publications/casestudies.

Cătoiu, I. (coord.) (2009), Cercetari de marketing, Tratat, București: Editura Uranus, p.56.

Clatici, V. G. et. al. (2017), Perceived Age and Life Style. The Specific Contributions of Seven Factors Involved in Health and Beauty, Maedica - A Journal of Clinical Medicine; 12(3): 112-122.

Congrese anti-aging (2017, September). Retrieved from www.congresantiaging.ro/ro Despre Ana Aslan (2016). Retrived from enciclopediaromaniei.ro/wiki/Ana_Aslan Enachescu, D., Marcu, M. (1998). Sanatate publicå si management sanitar, București: Editura All, pp. 65-67.

Filipovic, V. et al. (2010), Influence of healthcare institution managers proactive approach to communication activities on patient satisfaction. Journal of Health Care Marketing, Belgrade: Vojnosnitetski Pregled, 67(4), 267-271. 
Florescu, C., Malcomete, P., Pop, N. (2003). Marketing, Dicționar Explicativ, București: Ed. Economica, pp.12.

Fotea, I. S., Thomas, R. A., (2016), Business Ethics and Leadership from an eastern European, Transdisciplinary Context, Cham, Switzerland: Springer, p.43.

Genadinik, A., (2014). Event Planning- Management and Marketing for Successful Events, London: Ed. Independent Publishing Platform, p. 78.

Getz, D., Page, S.J. (2016). Event Studies: Theory, research and policy for planned events, London: Butterworth-Heinemann, p.90.

Gummeson, E. (2008). Total Relationship Marketing, Third edition, Boston, MA: Routledge, pp.102-104.

Hallowell, R. (1996). The relationships of customer satisfaction, customer loyalty and profitability International. Journal of Service Industry Management, 2(3), 27-42.

Hoyle, L.H. (2002). Event Marketing: How to Successfully Promote Events, Festivals, Conventions, and Expositions, Hoboken, NJ: John Wiley\& Sons Publishing, pp. 27-28.

Hunt, Sh. D., Morgan, R.M. (1995). The Comparative Advantage Theory of Competition, Journal of Marketing, 59 (4), 17-35.

ICCA Statistics Report (2016, June). Retrieved from www.iccaworld.org

Indounas, K., Arvanti, A. (2015). Success factors of new health-care services. Journal of Product and Brand Management, 24 (7), 693-705.

Ingram, S. (2014). Making Rain with Events, London: Ed. Certain, pp. 65-68.

International Meetings Statistics Report (2017, June). Retrieved from https://uia.org/publications.

Jolibert, A., Jourdan, Ph. (2011), Marketing Research. Méthodes de recherche et d'études en marketing, Paris: Dunod, pp. 95-96.

Kapferer, J., Bastien, V. (2012). The Luxury Strategy: Break the Rules of Marketing to Build Luxury Brands, Paris: Kogan Page Publishers, pp.32-33.

Kotler, P. (2000). Marketing Management: The Millennium Edition. Upper Saddle River, NJ: Prentice Hall, pp. 43.

Kotler, P. (2002). Principles of Marketing, Englewood Clifs, NJ: Prentice Hall, pp. 203-204

Kotler, P. et al. (2006). Marketing management, 12 edition, Upper Saddle River, NJ: Prentice Hall, pp. 145.

Kotler, P., Dipak, J., et. al.(2009). Marketingul in era digitala. O noua viziune despre profit, crestere si innoire (Original title: Marketing moves. A new approach of profits, growth and renewal), Bucuresti: Harvard Business Press, Meteor Business, pp. 12.

Kress, G. (1988). Marketing Research, Third Ed., Prentice-Hall Int., London, p. 120

Lendrevie, J., Levy, J. \& Lindon, D. (2006). Mercator, 8ème édition, Paris: Dalloz, p. 134-136.

Lhomme, A. (2000). Methodological manual for statistics on Congresses and Conferences, Luxembourg: European Communities.

Lonial, S. \& Raju, P. S. (2015). Impact of service attributes on customer satisfaction and loyalty in a healthcare context. Leadership in health services, 28 (2), 149-166.

Malhotra, N. K. \& Birks, D. F. (2003). Marketing Research. An Applied Approach, London: Pearson Education Ltd., pp. 17.

Meyer-Waarden, L. (2004). La fidélisation client. Stratégies, pratiques et efficacité des outils du marketing traditionnel, Paris: Vuilbert, pp. 20-22.

Moise, D. (2014). Marketingul si Managementul Evenimentelor, București: Editura ASE, pp. 56 
Morgan, R. M., Hunt, Sh. D. (1994). The Commitment -Trust Theory of Relationship Marketing, Journal of Marketing, 58(3) July, pp. 20-38.

Oliver, L. R. (1999). Whence Consumer Loyalty. Journal of marketing, 63(4), 33-44.

Pike, S. (2008). Destination Marketing- an Integrated Marketing Communication Approach, Oxford: Butterworth-Heinenmann, p. 66.

Plăiaș, I., (coord.) (2008). Cercetări de marketing, Cluj-Napoca: Editura Risoprint.

Pop, N. Al.(2006). A new paradigm in contemporary marketing: relationship marketing, Management \& Marketing, 1(3), 33-44.

Pop, N. Al. (2011). Marketing internațional: teorie și practică, Editura Uranus, București.

Pop, N. Al., Grozea, V. (2017), Current trends on the private medical market in Romania, Springer International Publishing.

Pop, N. Al., Roman, M., Săniuță, A., Petrișoaia, C., (2012). Relationship Marketing. Engine of Sustainable Development and Organizational Change in the Romanian Business Environment. Amfiteatru economic,XIV(32), 348-363.

Pop, N. Al., Vlădoi, A.D. (2009). The marketer - a complex specialist, a man of concept, decision and action. Amfiteatru economic, XI(25), 9-20.

Radulescu, A. (2017, August). Cea mai scumpă geantă din lume, 432.000 euro. Retrived

from www.qmagazine.ro/cea-mai-scumpa-geanta-din-lume-432-000-euro

Raj, R., Walters, P., Rashid, T. (2009). Events Management- An Integrated and Practical Approach, London: Ed. Sage Publications, pp.78.

Saget, A. (2006). The Event Marketing Handbook: Beyond Logistics \& Planning, New York, NY: Dearbon Trade Publishing, pp.52-54.

Shone, A., Bryn,P. (2013). Successful Event Management: A Practical Handbook, Fourth Edition, Hampshire, UK: Cengage Learning, pp.130-132.

Stăncioiu, A. (2005). Planificarea de marketing în turism, București: Editura Economică, p.67

Stănciulescu, G. (2010), Managementul operatiunilor in turismul de evenimente, București: Editura ASE, p.34

Tandon, A., Murray, C., Lauer, J., (2000). Measuring overall health system performance for 191 countries, Geneva: World Health Organization.

Vorzsak, A. (coord) (2008). Marketingul serviciilor de sanatate, București: Ed. Uranus, p.49.

Wali, A., Wright, L. \& Uduma, I. (2015). Customer relationship management for brand commitment and brand loyalty. British Journal of Marketing Studies, 3(4), 45-58.

Wang, Y. \& Lo, H.-P. (2003). Customer-focused Performance and the Dynamic Model for Competence Building and Leveraging. Journal of Management Development, 22(6), 483-526.

Weng, R-H. et al. (2016). The Impact of market orientation on patient safety climate among hospital nurses. Evaluation \& the health professions, 39(3), 204-227.

White, C. \& Yu, T. (2005). Satisfaction emotions and consumer behavioral intentions. Journal of Services Marketing, 19(6), 411- 420. 